
ВИКОРИСТАННЯ ЕЛЕМЕНТІВ МЕДІАКУЛЬТУРИ, ІНФОГРАФІКИ
ТА ХМАРНИХ СЕРВІСІВ НА УРОКАХ ЗАРУБІЖНОЇ ЛІТЕРАТУРИ

\title{
USE OF MEDIA CULTURE ELEMENTS, INFOGRAPHICS AND CLOUD SERVICES AT THE LESSONS OF FOREIGN LITERATURE
}

Запровадження елементів медіакультури, інфоографріки та використання хмарних сервісів - це вимога часу, яка дає можливість орормувати творчо обдаровану дитину в умовах нестандартного підходу до побудови структури сучасного уроку зарубіжної літератури. Комп'ютерні технології $є$ інноваційною альтернативою застарілим методам навчання і здатні полегшити роботу вчителя та зацікавити учня, а процес здобуття знань зробити сучасним. Упровадження нових ефрективних технологій навчання - важливе завдання, яке стоїть перед педагогом нової української школи. Прочес реорормування освіти потребує нової та якісної підготовки до уроків, максимального застосування інноваційних технологій. Тому питання використання елементів медіакультури, інфрографріки, хмарних сервісів є актуальним та важливим. Перед сучасним педагогом постає важливе завдання - навчити молоде покоління розуміти медіаінфоормацію, мати уявлення про механізми їі впливу на глядача, слухача та читача. Розвиток засобів масової інфрормації та їх залучення до процесів навчання i виховання значно активізували творчий пошук педагогів. Час вимагає від учителя й учня медіаграмотності, щоб досягти якісно нових результатів, тому медіакультура як набір засобів і методів навчання молоді зараз, як ніколи, актуальна. Сучасні дітu - че діти екранної інсрормації. Медіаматеріал екрана, монітора, інтерактивної дошки, проєктора, телевізора, ґаджета сприймається краще i швидше. Це той важливий чинник, на який сучасний учитель не має права не зважати, коли готується до спілкування з учнями. Велику користь для школярів має розуміння ними соціальних, культурних, політичних та економічних підтекстів медіатекстів. Тому перед учителем постало завдання розвивати в учнів здібності до естетичного сприйняття, оцінки естетичних якостей, сприйнятих і створених ним медіатекстів. Медіаосвітні технології спрямовані на розвиток умінь і навичок учнів: здатності і готовності докладати зусилля, щоб сприймати, розуміти зміст медіатексту, ступінь його впливу. Нові інформаційні технології інфрормаційного суспільства змінюють умови навчання, а медіа стають невід'ємною частиною загальної культури дитини-школяра. За допомогою медіа дитина здобуває інфрормаційну свободу, вчиться мислити самостійно, творчо, критично.

Ключові слова: медіакультура, медіатехнології, медіатекст, інфрографріка, хмарні сервіси, інноваційні технології, робота з обдарованими учнями, критичне мислення.
The introduction of media culture elements, infographics and the use of cloud services can be explained by a call of the times, which allows us to form a creative child taking into consideration a non-standard approach to creating the structure of a modern lesson of foreign literature. Computer technology is an innovative alternative to outdated teaching methods and can be used to facilitate the teacher's work and to make the lesson interesting to a student as well as to make the process of acquiring knowledge modern. The introduction of new effective teaching technologies is an important task the NUS (New Ukrainian School) teacher faces. The process of reforming education requires new and highquality preparation for lessons, maximum use of innovative technologies. Therefore, the issue of using media culture elements, infographics, and cloud services is relevant and important. The modern teacher faces an important task which is to teach the younger generation to understand media information, its mechanisms of influence on the viewer, listener and reader. The development of mass media and its involvement in the process of teaching and education has significantly intensified the creative search for teachers. Nowadays it is essential for the teacher and the student to be media literate to achieve qualitatively new results, so media culture, as a set of tools and methods of teaching young people, is more relevant today than ever. Modern children are children of screen information. The media materials of the screen, monitor, interactive whiteboard, projector, TV set, and gadgets are perceived better and faster. This is an important factor that a modern teacher has no right to ignore when preparing to communicate with students. It is very useful for students to understand the social, cultural, political and economic subtexts of media texts. Therefore, the teacher has been faced with the task of developing students ability to aesthetic perception, assessment of aesthetic quality of his perceived and created media texts. Media education technologies are aimed at developing students' skills and abilities: the ability and willingness to make efforts to perceive, understand the content of the media text, the degree of its impact. New information technologies in the information society are changing the teaching and learning environment, and the media is becoming an integral part of the overall culture of a school child. A child acquires information freedom, and to think independently, creatively, critically with the help of the media.

Key words: media culture, media technologies, infographics, media text, cloud services, innovative technologies, work with gifted students, critical thinking.
Постановка проблеми в загальному вигляді. Запровадження елементів медіакультури, інфрограсіки та використання хмарних сервісів - це вимога часу, яка дає можливість формувати творчо обдаровану дитину в умовах нестандарт- ного підходу до побудови структури сучасного уроку зарубіжної літератури. Комп'ютерні технології $€$ інноваційною альтернативою застарілим методам навчання і здатні полегшити роботу вчителя та зацікавити учня, а процес здобуття знань 
зробити сучасним. Упровадження нових ефективних технологій навчання - важливе завдання, яке стоїть перед педагогом нової української школи (далі - НУШ).

Аналіз останніх досліджень і публікацій. Процес рефрормування освіти потребує нової та якісної підготовки до уроків, максимального застосування інноваційних технологій. Тому питання використання елементів медіакультури, інорографоки, хмарних сервісів $є$ актуальним та важливим. Свідченням цього є наукові дослідження І. Дичківської, О. Шабунової, О. Глазової, Т. Архипової, В. Гриценка, В. Іванова, О. Пометун та інших. Використання елементів медіа, інфографріки, хмарних сервісів досліджують також В. Назаренко, М. Ватковська, звертають увагу на важливість інформаційного суспільства та вплив засобів масової інорормації (далі - ЗМІ) на процес виховання нової особистості, досліджують водночас питання історії медіаосвіти, інфрографріки та сучасного програмного забезпечення. Віртуальна діяльність вчителя й учня - важлива складова частина НУШ, яка потребує подальших розробок і активного впровадження у практику педагогічної діяльності вчителя.

Виділення не вирішених раніше частин загальної проблеми. У роботі висвітлено питання про використання елементів медіакультури, інфрографріки та хмарних сервісів на уроках зарубіжної літератури як важливого засобу розвитку творчо обдарованої дитини в умовах нестандартного підходу до побудови сучасного уроку зарубіжної літератури, формування критичного мислення, що $є$ основним у вихованні соціально активної особистості, здатної творчо засвоювати знання і використовувати їх на практиці, особистості, від якої залежить майбутнє нашої держави.

Мета статті. Визначити специфрічні особливості використання елементів медіакультури, інфографріки та хмарних сервісів на уроках зарубіжної літератури як інноваційного засобу сучасної освіти, проаналізувати основні атрибути медіатехнологій, спроєктувати всі переваги їх застосування в навчальному процесі.

Виклад основного матеріалу. Початок XXI ст. характеризується створенням світової інфрормаційної структури, розвитком різних інформаційноінноваційних технологій, зокрема й у сфері освіти, завданням якої $€$ фрормування вміння швидко орієнтуватися в потоці інформації, що стрімко зростає. Зі школи учень повинен виносити не просто обсяг знань, а й уміння вчитися, уміння жити в суспільстві, бути компетентним.

Нині, щоб бути професіоналом у будь-яких питаннях, потрібно щодня перечитувати газети, журнали, переглядати передачі, знайомитися 3 ресурсами інтернету, уміло відбирати позитив у потоці інформації, вчити цьому дітей. Перед сучасним педагогом постає важливе завдання навчити молоде покоління розуміти медіаінорормацію, мати уявлення про механізми її впливу на глядача, слухача та читача. Розвиток засобів масової інфрормації та їх залучення до процесів навчання і виховання значно активізували творчий пошук педагогів. Час вимагає від учителя й учня медіаграмотності, щоб досягти якісно нових результатів, тому медіакультура як набір засобів і методів навчання молоді нині, як ніколи, актуальна.

Сучасні діти - це діти екранної інформації. Медіаматеріал екрана, монітора, інтерактивної дошки, проєктора, телевізора, ґаджета сприймається краще і швидше. Це той важливий чинник, на який сучасний учитель не має права не зважати, коли готується до спілкування з учнями. Але це в жодному разі не означає, що дитина повинна черпати знання лише з екрана. Це, навпаки, у разі умілої організації уроку з боку вчителя допомагає, розвиває, навчає.

Медіаосвіта у школі сприяє забезпеченню учня знаннями про те, як:

- аналізувати, критично мислити;

- створювати власну медіапродукцію;

- застосовувати свої вміння на практиці під час вивчення будь-якого предмета.

Велику користь для школярів має розуміння ними соціальних, культурних, політичних та економічних підтекстів медіатекстів. Тому перед учителем постало завдання розвивати в учнів здібності до естетичного сприйняття, оцінки естетичних якостей, сприйнятих і створених ним медіатекстів.

Медіаосвітні технології спрямовані на розвиток умінь і навичок учнів: здатності і готовності докладати зусилля, щоб сприймати, розуміти зміст медіатексту, ступінь його впливу. Нові інорормаційні технології інорормаційного суспільства змінюють умови навчання, а медіа стають невід'ємною частиною загальної культури дитини-школяра. За допомогою медіа дитина здобуває інфрормаційну свободу, вчиться мислити самостійно, творчо, критично [1, с. 72].

Підготовка до уроку літератури вимагає високої культури, ґрунтовних фрахових знань, умілого володіння живим словом, тому знання основ медіакультури $€$ важливим чинником у фрормуванні сучасної креативної, самодостатньої особистості.

У роботі вчителя-словесника важливу роль відіграють інформаційні комп'ютерні технології, які дозволяють зробити процес навчання мобільним, строго дисеренційованим та індивідуальним. Комп'ютер став для сучасного школяра партнером, здатним допомагати в освоєнні знань, а також спонукати як учня, так і вчителя шукати нові, нетрадиційні форми і методи навчання: створити власну медіапродукцію; презентацію з певної теми, озвучити її (програма Windows Movie Maker), підготувати програму засідання клубу 
«Книга вчить, як на світі жить» (програма Page Maker), скласти тести до теоретичної статті підручника (mozaBook) тощо.

Застосування засобів IKT у системі освіти насамперед спрямоване на вдосконалення наявних технологій навчання. Комп'ютерні технології підсилюють дослідницькі, інформаційнопошукові й аналітичні методи роботи 3 навчальним матеріалом. Дитина, коли створює власну медіапродукцію, вірить у важливість виконаної роботи, виявляє творчість, вчиться працювати колективно і в колективі. Звичайно, важливо нормувати час роботи 3 комп'ютером, щоб не порушувати санітарно-гігієнічні норми і не перетворювати спілкування 3 «технічним словом» на спосіб життя.

IКT, на нашу думку, відіграють важливу роль у фрормуванні та розвитку читацької культури. Основна мета використання таких засобів - активізувати пізнавальну діяльність учнів, підсилити самостійність в опануванні знань, умінь і навичок, мотивацію й інтерес до навчання, отже, і поліпшити навчальні досягнення школярів.

Нині в суспільстві виникла потреба у творчих, діяльних і обдарованих, інтелектуально й духовно розвинених громадянах. Саме від творчих людей залежить розвиток суспільства. Творчі здібності характеризуються як властивості особистості, що забезпечують успіх у будь-якій діяльності. «Так, на основі власного педагогічного досвіду дійшли висновку, що ці здібності включають основні чотири компоненти: мотиваційний (допитливість, творчий інтерес, прагнення досягнень); інтелектуально-логічний (уміння аналізувати, виділяти головне, класифікувати); інтелектуально-евристичний (уміння франтазувати, висувати гіпотези, критично мислити); комунікативний (уміння сприймати усне та письмове мовлення, самостійно будувати висловлювання)» [3, с. 7]. Отже, використання інфографріки та хмарних сервісів сприяє розвитку неординарного мислення, творчої уяви.

Інфрографріка - графрічне візуальне подання інорормації, даних або знань, призначених для швидкого та чіткого відображення комплексної інорормації. Вона може покращити сприйняття інформації, використовує графрічні матеріали для того, щоб підвищити можливості зорової системи людини бачити моделі та тенденції. Процес створення інфографріки можна розглядати як візуалізацію даних, створення інформаційних схем та моделей подання інорормації. Завдяки інорографріці навіть складні теми подаються легко і швидко. Інфографріка - модний тренд, що успішно увійшов у світ інфрормації. У підручниках з української мови та літератури ми досить часто спостерігаємо компактну подачу матеріалу саме ву малюнках та схемах, що допомагає учням і вчителю на будь-якому етапі уроку. Отже, інфрографріку доцільно використовувати:

- під час вивчення нового матеріалу;

- під час закріплення нової теми;

- для перевірки знань;

- для розв'язання проблемних питань;

- як засіб емоційного розвантаження.

Сучасний учитель - це людина, яка йде в ногу із часом, добре відчуває потребу суспільства у змінах та прагне сприяти інноваціям в освіті. Тому хмарні технології - це важливий спосіб отримання та надання інорормації, бо, за словами В. Назаренка, «<...> надають можливість усім педагогам та учням віддалено користуватися програмним забезпеченням, що надається у хмарі» [7, с. 99].

Соціальні сервіси дають безліч можливостей. Їх застосування в педагогічній діяльності зумовлено часом, потоками інорормації, що постійно зростають, швидкістю їх обробки та її пошуком. Але який би сервіс ми $з$ вами не розглядали - він $€$ лише інструментом. I як ми його будемо застосовувати у своїй діяльності, залежить тільки від нас.

«Хмарні технології - це парадигма, що передбачає віддалену обробку та зберігання даних. Ця технологія надає користувачам мережі Інтернет доступ до комп'ютерних ресурсів сервера і використання програмного забезпечення як онлайнсервісу» [5, с. 29].

У результаті поширення соціальних сервісів у мережевому доступі виявляється величезна кількість матеріалів, які можна використовувати на уроках та в позаурочний час. Цікавими є можливості програмного забезпечення Adobe, Ilustrator, за допомогою яких можна створити інфрографіку, редагувати вже готові схеми. А сервіс Pictochart. com містить шаблони для створення інфографіки та графічних презентацій. Діти із задоволенням використовують всі можливості комп'ютера, коли працюють над проєктами. Під час створення презентацій до проєктів «Шістдесятництво в українській культурі», «3 історії частин мови» вдало скористалися програмами mozaBook та mozaVeb, які допомогли створити стрічку часу (коли водночас можна побувати в усіх місцях, де проживали шістдесятники), карту знань (відображає структуру будь-якого розділу мовознавства тощо), інтерактивні плакати (мультимедійний постер, на якому водночас представлені тексти, фото, відео, інфрографріка).

На уроках зарубіжної літератури доречно звертатися до електронних ресурсів: перегляд навчальних документально-біографрічних фрільмів, що справляють велике враження на учнів, або історичних довідок про різних особистостей царини літературознавства. Цікавим елементом рефрлексії є пропозиція учителя продовжити думку:

- сьогодні на уроці я зміг віртуально відвідати $<\ldots>$ і відзначив, що <...>; 
- якщо я докладу зусиль, то <...>;

- інфрормація, яку я отримав сьогодні на уроці, допоможе мені <...>;

- урок пройшов <...>.

Матеріали фронохрестоматії можна використовувати 3 метою ознайомлення дітей із голосом і манерою виконання знаменитих письменників і акторів.

Учні на уроках літератури повинні не просто споглядати якусь презентацію чи відеоролик, а ще й виконувати заздалегідь запропоновані проблемні завдання: записувати основні біографрічні факти із життя митця, складати тезисний чи простий план, що, у свою чергу, дає можливість розвивати загальнонавчальні вміння та навички. Після перегляду учні обов'язково обмінюються думками, зачитують конспекти чи тези, заповнюють слоти, створюють власні висловлювання.

Одним з елементів медіакультури, який можна використовувати на уроках, є перегляд фррагментів екранізації художніх творів. Перегляд повинен супроводжуватися завданнями. Найбільш поширені такі:

- Які події передували даному моменту і які будуть далі?

- Чи збігаються ваші уявлення про героїв 3 авторськими?

- Які риси зовнішності героя взяли до уваги творці фрільму?

- Щоб ви порадили героям та режисеру-постановнику фрільму?

Отже, відеофрагмент використовується як ілюстрація до твору, фрормує вміння критично мислити, мати власний погляд на побачене, прочитане, почуте; вчить висловлювати думки грамотно, чітко, виразно. Учні вчаться зіставляти авторські та режисерське бачення проблем художнього тексту. Такі уроки сприяють розширенню кругозору дітей, фрормують активну життєву позицію. Учні не просто переглядають фрільм, вони аналізують побачене, висловлюють думку, вчаться писати власне висловлювання.

Висновки. Отже, нові комунікаційні технології інфрормаційного суспільства змінюють умови навчання. Медіа вже стали невід'ємною частиною загальної культури учня. За допомогою ЗМІ та IKT особистість здобуває інформаційну свободу, вчиться мислити самостійно, критично, творчо. А доступ до хмарних сервісів - дієвий засіб активізації пізнавальної діяльності учнів. Використання на уроках зарубіжної літератури елементів медіакультури, інфографріки, хмарних технологій дає можливість розвивати індивідуальні та пізнавальні здібності кожної дитини; максимально виявити індивідуальний досвід учня; сприяти формуванню творчої особистості; формувати культуру користування інтернет-ресурсами; навчити учнів максимально і 3 користю застосовувати можливості комп'ютера; удосконалити вміння та навички створення власної медіапродукції.

Медіакультура нині передбачає залучення до навчального процесу як традиційних засобів масової інформації, так і новітніх: учні самі добирають матеріал, оцінюють медіатексти, відбирають необхідне відповідно до потреб. Отже, урок стає співдружністю учителя, учня та медіа, яка сприяє розвитку креативності. Використання елементів медіакультури, інфрографріки та хмарних сервісів - це інновації, які спрямовані на розвиток і виховання всебічно розвиненої креативної особистості.

\section{БІБЛІОГРАФІЧНИЙ СПИСОК:}

1. Архипова Т., Зайцева Т. Технології «хмарних обчислень» в освітніх закладах. Хмарні технології в освіті : матеріали Всеукраїнського науково-методичного інтернет-семінару, 21 грудня 2012 р., Кривий Ріг. C. 72-74.

2. ВакалюкТ. Хмарнітехнології в освіті : навчальнометодичний посібник. Житомир : ЖДУ, 2016. 72 с.

3. Глазова О. Робота над медіатекстом на уроках мови як перший крок до впровадження шкільної медіаосвіти. Методичні діалоги. 2010. № 7/8. С. 7-9.

4. Гольцова К. Інфрографріка як засіб активізації навчально-пізнавальної діяльності учнів. URL: http:// informatika.udpu.org.ua/?page_id= 2771ua/?page_ $\mathrm{id}=2771$ (дата звернення: 06.12.2020).

5. Гриценко В. Формування навчального середовища 3 використанням соціальних хмарних сервісів. Хмарні технології в освіті : Всеукраїнського науково-методичного інтернет-семінару, 21 грудня 2012 р., Кривий Ріг. С. 29-30.

6. Медіаосвіта та медіаграмотність : короткий огляд / В. Іванов та ін. Київ : АУП, ЦВП, 2012. 58 с.

7. Назаренко В. Переваги і перспективи використання хмарних технологій у навчально-виховному процесі. Нова педагогічна думка. 2016. № 4. C. 97-99.

8. Нова українська школа : основи Стандарту освіти. URL: http://www.osvitportal.lviv.ua/ upload/users_files/1/upload/1/nova\%20schkola $\% 20$ (pantone\%208703\%20C)-ilovepdf-compressed.pdf (дата звернення: 06.12.2020). 